\title{
The Relationship Between Emotional Intelligence and Leadership Effectiveness Among Coaches at The XYZ Training Center
}

\section{Hubungan di antara Kecerdasan Emosi dan Keberkesanan Kepimpinan dalam Kalangan Jurulatih di Pusat Latihan XYZ}

\author{
Fadillah Ismail $^{1 *}$, Nur Amalina Mohd Rosli ${ }^{1}$, Adibah Abdul Kadir ${ }^{1}$ \\ ${ }^{1}$ Fakulti Pengurusan Teknologi dan Perniagaan (FPTP), \\ Universiti Tun Hussein Onn Malaysia, MALAYSIA \\ *Corresponding Author
}

DOI: https://doi.org/10.30880/jstard.2020.02.03.018

Received 30 September 2020; Accepted 30 November 2020; Available online 31 December 2020

\begin{abstract}
Emotional intelligence plays a very important role for a leader because it can help the effectiveness of coach leadership among trainees and can even guarantee the transfer of training that has been given to trainees. When there is a failure to curb this situation will have a more negative impact on organizations and individuals, and if it is not proactively addressed. Therefore, this study aims to identify the level and relationship between emotional intelligence and leadership effectiveness among coaches. A total of 74 sets of questionnaires were distributed to respondents who have participated in the Transformation Program (Team Building) organized by XYZ training center on October 20, 2018 until October 22, 2018. Descriptive analysis shows the results of the study on emotional intelligence level and leadership effectiveness among coaches. While the correlation analysis proves that there is a significant relationship with $r=0.828$ between emotional intelligence and leadership effectiveness among coaches. Thus, this study has shown that emotional intelligence has a significant relationship with leadership effectiveness among coaches.
\end{abstract}

Keywords: Emotional intelligence, coach, leardership, training 


\begin{abstract}
Abstrak: Kecerdasan emosi memainkan peranan yang sangat penting bagi seorang pemimpin atau ketua kerana ia dapat membantu keberkesanan kepimpinan jurulatih dalam kalangan pelatih malah dapat menjamin pemindahan latihan yang telah diberikan kepada para pelatih. Ini kerana kegagalan membendung situasi ini akan membawa impak yang lebih negatif terhadap organisasi dan individu sekiranya ia tidak diatasi secara proaktif. Maka kajian ini bertujuan untuk mengenal pasti tahap serta hubungan antara kecergasan emosional dan keberkesanan kepimpinan dalam kalangan jurulatih. Sejumlah 74 set soal selidik diedarkan kepada responden yang telah menyertai Program Transformasi (Team Building) anjuran pusat latihan XYZ pada 20 Oktober 2018 sehingga 22 Oktober 2018. Analisis deskriptif menunjukkan hasil kajian terhadap tahap kecergasan emosi dan tahap keberkesana kepimpinan dalam kalangan jurulatih. Manakala analisis korelasi membuktikan terdapat hubungan yang signifikan dengan $\mathrm{r}=0.828$ di antara kecerdasan emosi dan keberkesanan kepimpinan dalam kalangan jurulatih. Justeru kajian ini telah menunjukkan bahawa kecerdasan emosi mempunyai hubungan yang signifikan dengan keberkesanan kepimpinan dalam kalangan jurulatih.
\end{abstract}

Kata Kunci: Kecerdasan emosional, jurulatih, keberkesanan kepimpinan, latihan

\title{
1. Pengenalan
}

Pembangunan dan pergerakan era yang sangat pantas mencabar pelajar menghadapi gelombang globalisasi. Maka, keupayaan untuk mengawal emosi menjadi semakin penting agar menjadi individu yang berguna. Kecerdasan emosi yang tinggi membantu mengekalkan keharmonian dalam diri seseorang dan menjadikannya berkeyakinan dalam mengatasi cabaran hidup dan juga pembelajaran di institusi pengajian. Kecerdasan emosi merupakan suatu kecekapan emosi dan sosial serta kemahiran dalam menentukan seberapa cekapkah seseorang memahami emosi sendiri dan mempamerkannya, memahami emosi orang lain dan berhubung dengannya serta bagaimana seseorang mengatasi kehendak dan tekanan yang dilalui dalam kehidupan seharian [1].

Kecerdasan emosi merupakan separuh daripada semangat manusia yang memotivasikan seseorang untuk melakukan sesuatu serta memberi tenaga kepada seseorang [2]. Lam dan Kirby (2002) berpendapat kecerdasan emosi terdiri daripada mengenalpasti emosi, memahami emosi dan mengawal emosi. Dalam persekitaran kerja hari ini, kekurangan berterusan pekerja mahir dan pakar-pakar dan generasi yang menyertai tenaga kerja yang lebih arif mengenai teknikal, yang berkaitan dan mudah alih daripada mana-mana generasi lain sebelum (Bristow et al. 2011) kepimpinan mendapat kepentingan dan oleh itu kajian focus kepada penyelidikan dari sudut pengurusan.

Kajian mengenai kecerdasan emosi dalam konteks kepimpinan terus menjadi bidang kajian yang diminati pengkaji dalam atau luar negara lebih daripada sepuluh tahun [1]. Ini menunjukkan bahawa ekspresi emosi pemimpin di tempat kerja sebagai contohnya $[1,2]$ begitu juga dengan gaya kempimpinan yang memberi kesan kepada emosi seseorang pekerja $[1,3]$.

Kajian lepas mengenai kepemimpinan di sektor swasta dan perniagaan nampaknya lebih luas daripada literatur mengenai kepemimpinan di sektor pendidikan. Walaupun kajian yang ada memperincikan seperti apa pemimpin, dan bagaimana mereka membuat keputusan, peranan kecerdasan emosi dalam proses kepemimpinan belum banyak diteliti. Walaupun terdapat hubungan teori antara kecerdasan emosi dan kepemimpinan, terdapat sedikit kajian empirikal yang mengkaji hubungan antara kecerdasan emosi di tempat kerja dan kepemimpinan yang berkesan [3]. Sebagai tinjauan literatur mengenai kecerdasan emosi dan keberkesanan kepemimpinan menunjukkan masih banyak yang perlu dipelajari mengenai konstruk yang sukar difahami ini dan hubungannya dengan kepemimpinan yang berkesan. Hal ini kerana selain daripada kecerdasan intelek, kecerdasan emosi dikatakan turut memainkan peranan dalam menentukan kejayaan dan kehidupan peribadi seseorang [4]. Justeru kajian-kajian yang berhubung dengan kecerdasan emosi (EQ) dan keberkesanan kepimpinan jurulatih dalam di pusat latihan di Malaysia amat kurang dan wajar diterokai supaya hasil kepimpinan tersebut dalam dilihat melalui pelatih pada masa akan datang.

Menurut Baesu (2019), keberkesanan kepemimpinan digambarkan sebagai seimbang dan teliti. Pemimpin yang berkesan mempunyai kemampuan yang bijak untuk mengetahui bila, bagaimana, dan apa yang perlu dilakukan [3]. Lebih jauh lagi, kepentingan kecerdasan emosi dalam peranan kepemimpinan seperti jurulatih tidak boleh dianggap remeh. Pada kajian terkini dalam penyelidikan mengesahkan bahawa kecerdasan emosi berkorelasi dengan hampir 90\% amalan kepemimpinan yang berkesan [1].

Bukti yang kuat telah mendorong para penyelidik untuk menunjukkan bahawa kemampuan intelektual, seperti yang sering diukur oleh ujian Intelligence Quotient (IQ), sangat berkaitan dengan fungsi psikologi atau emosi. Walaupun terdapat lebih daripada 200 penerbitannya dalam bidang psikologi, hampir setiap pelajar psikologi pengantar mengetahui bahawa Alfred Binet membuat ujian Intelligence Quotient (IQ) pada tahun 1908; dan ramai yang percaya bahawa skor IQ adalah sumbangan Binet yang paling signifikan dalam bidang psikologi. Namun, banyak karya Binet sebelumnya "tertumpu pada tujuan memahami dan mengukur perbezaan individu dalam kecerdasan" [5]. Alasan yang mengambil kira emosi biasanya disebut sebagai kecerdasan emosi. 
Menurut Wills (2018), kecerdasan emosi merangkumi kemampuan seseorang untuk melihat dan memahami emosi dan pengetahuan emosi, kemampuan untuk memahami emosi seseorang sehingga mereka dapat mempromosikan persekitaran emosi intelektual, dan untuk mengakses dan menjana emosi untuk membantu berfikir [6]. Kajian mengenai jurulatih menunjukkan bahawa kehadiran kecekapan kecerdasan emosi dan kemampuan menguruskannya adalah yang membezakan pemimpin yang berkesan dengan yang tidak berkesan [7].

Dalam sebuah kajian yang dijalankankan oleh Rathor \& Pandey (2018), penyelidik mendapati bahawa individu dengan kecerdasan emosi yang baik mampu membuat keputusan dengan baik, menyelesaikan masalah, serta mempunyai sikap yang positif di tempat kerja [7]. Kecerdasan emosi yang baik juga mampu membuahkan hasil kerja yang cemerlang dalam diri seseorang serta pada masa yang sama memberi kesan yang baik kepada organisasi [8]. Namun begitu, seseorang yang mempunyai kecerdasan emosi yang kurang memberangsangkan pula berhadapan dengan kesukaran dalam perhubungan, malah turut sukar mengadaptasikan diri serta mempunyai kerjaya yang tidak berada pada tahap tertinggi [9]. Akibatnya, amalan tersebut akan memberi kesan negatif kepada kejayaan individu malah turut memberi kesan kepada organisasi.

Berdasarkan kepada kajian literatur turut menunjukkan antara hubungan kecerdasan emosi dan keberkesanan kepimpinan. Kecerdasan emosi merupakan antara tunggak utama yang menentukan kemerlangan sesorang secara umum, namun kecerdasan emosi akan menjadi lebih penting buat seseorang yang bergelar pemimpin dalam organisasi [10]. Hasil kajian tersebut menunjukkan betapa pentingnya kecerdasan emosi dalam meningkatkan kepimpinan sebagai ketua di pusat latihan. Seseorang dengan keupayaan kecerdsan emosi yang rendah tidak mampu menjadi pemimpin yang berkesan. Ini adalah kesan daripada kecerdasan emosi yang mempunyai kesan yang begitu penting dari dari pelbagai sudut $[11,12]$.

Hasil daripada permasalahan di atas, kecerdasan emosi mampu membentuk keberkesanan kepimpinan dalam diri seseorang. Kajian turut menunjukkan bahawa para pelatih mempunyai peranan penting dari aspek kecerdasan emosi untuk melahirkan pelatih yang cemerlang. Tahap kecerdasan emosi yang sederhana atau rendah akan menjejaskan prestasi mereka untuk berfungsi dengan cemerlang. Oleh yang demikian, satu kajian perlu dilakukan dari aspek hubungan kecerdasan emosi dengan kepimpinan dalam kalangan jurulatih di pusat latihan XYZ.

Kajian ini dijalankan berasaskan kepada beberapa objektif yang telah dikenal pasti. Objektif tersebut adalah seperti berikut:

i. Mengkaji tahap kecerdasan emosi dalam kalangan jurulatih di Pusat Latihan XYZ.

ii. Mengkaji tahap keberkesanan kepimpinan dalam kalangan jurulatih di Pusat Latihan XYZ.

iii. Mengkaji hubungan antara hubungan diantara kecerdasan emosi dan keberkesanan kepimpinan dalam kalangan jurulatih di Pusat Latihan XYZ.

\section{Kajian Literatur}

\section{Keberkesanan Kempimpinan}

Walaupun para sarjana pengurusan berbeza dalam memberikan definisi mereka tentang keberkesanan kepimpinan, namun konstruk utama kepimpinan adalah berkaitan dengan tanggungjawab pemimpin itu sendiri. Kepimpinan yang berkesan memerlukan pandangan peribadi yang mendalam [13], dan pemimpin perlu mempunyai satu set yang kompleks tentang tugas moral kepada diri mereka sendiri dan lain-lain [14].

Kouzes dan Posner (2012) menekankan bahawa pemimpin perlu menjalankan tugas moral kepada pihak berkepentingan untuk mewujudkan kejayaan jangka panjang dan membantu pekerja untuk mencapai potensi tertinggi mereka [15]. DePree (2004) menyifatkan pemimpin sebagai "hamba dan penghutang" dalam memberikan senarai tugas mereka [16]. Seterusnya, Paine (2002) menekankan bahawa pemimpin mencapai prestasi yang tinggi hanya apabila mereka mencapai imperatif kewangan sosial dan memainkan peranan normatif dalam mewujudkan organisasi yang berasaskan nilai dan prinsip [17].

Para sarjana lain telah menekankan kewajipan pemimpin untuk menjadi "penjaga" yang berkhidmat kepada orang lain [18]. Trevino dan rakan-rakan (2000) menjelaskan bahawa pemimpin yang beretika adalah "orang moral" dan "pengurus moral" kedua-duanya yang memberi contoh atau model untuk mencapai hasil sesebuah organisasi yang optimum [19]. Cameron (2011) menyatakan bahawa pemimpin mempunyai tanggungjawab untuk menjadi orang yang benar-benar "mulia" dalam mewujudkan kejayaan, menghormati tugas, dan menambah nilai anak buah mereka [20]. Begitu juga Shao et al. (2008) menekankan bahawa identiti peribadi dan identiti moral pemimpin mesti bergabung yang dilihat sebagai mereka yang boleh dipercayai dan jujur [21].

Pemimpin mestilah mengimbangi perspektif etika yang bercanggah untuk mencapai rangka kerja dari segi moral yang kukuh [22]. Pemimpin yang bermoral tidak membahayakan, mewujudkan nilai dalam jangka masa pendek, dan mewujudkan nilai dalam jangka masa panjang [23]. Keupayaan untuk mengimbangi jangkaan yang tidak sama dan permintaan yang kompleks memerlukan pemimpin memahami siapa mereka, apa yang mereka nilai, dan akibat daripada tindakan mereka [24]. 


\section{Kecerdasan Emosi}

Kecerdasan Emosi adalah keupayaan untuk mengenal pasti, memahami, dan menggunakan emosi secara positif untuk mengurus kegelisahan, berkomunikasi dengan baik, berempati, mengatasi masalah, menyelesaikan masalah, dan mengurus konflik. Menurut model keupayaan kecerdasan emosi, ini adalah persepsi, penilaian, dan pengurusan emosi dalam diri anda dan orang lain [25]. Kecerdasan Emosi, atau kemampuan untuk melihat, menggunakan, memahami, dan mengatur emosi, adalah konsep yang agak baru yang cuba menghubungkan emosi dan kognisi [26].

Kecerdasan Emosi pertama kali muncul dalam konsep "kecerdasan sosial" Thorndike pada tahun 1920 dan kemudian dari psikologi Howard Gardner yang, pada tahun 1983, mengesyorkan teori kecerdasan pelbagai, dengan alasan bahawa kecerdasan merangkumi lapan bentuk. Ahli psikologi Amerika Peter Salovey dan John Mayer, yang bersama-sama memperkenalkan konsep pada tahun 1990 [27], mendefinisikan kecerdasan emosi "sebagai kemampuan untuk memantau emosi seseorang dan orang lain, untuk melakukan diskriminasi di antara mereka, dan menggunakan maklumat untuk membimbing pemikiran dan tindakan seseorang " Orang yang telah mengembangkan kecerdasan emosi mereka mempunyai keupayaan untuk menggunakan emosi mereka untuk mengarahkan fikiran dan tingkah laku dan memahami perasaan mereka sendiri dan perasaan orang lain dengan tepat. Daniel Goleman, seorang penulis Amerika, psikologi, dan wartawan sains, mengungkapkan konsep EI dalam bukunya yang diberi nama "Emotional Intelligence" [28, 29, 30]. Dia memperluas konsep untuk merangkumi kecekapan sosial umum. Goleman mencadangkan bahawa EI sangat diperlukan untuk kejayaan hidup seseorang.

Mayer dan Salovey mencadangkan bahawa EI adalah kemampuan kognitif, yang terpisah tetapi juga dikaitkan dengan kecerdasan umum. Secara khusus, Mayer, Salovey, Caruso, dan Sitarenios [31] mencadangkan bahawa kecerdasan emosi terdiri daripada empat dimensi kemahiran: (1) memahami emosi (iaitu, keupayaan untuk mengesan emosi dalam wajah, gambar, muzik, dll.); (2) memfasilitasi pemikiran dengan emosi (iaitu, kemampuan memanfaatkan maklumat emosi dalam pemikiran seseorang); (3) memahami emosi (iaitu keupayaan untuk memahami maklumat emosi); dan (4) mengurus emosi (iaitu, kemampuan mengurus emosi untuk perkembangan peribadi dan interpersonal). Kemahiran ini disusun secara hierarki sehingga emosi persepsi mempunyai peranan penting untuk memudahkan berfikir, memahami emosi, dan mengurus emosi. Cabang-cabang ini berpunca dari kemahiran asas yang lebih tinggi, yang berkembang ketika seseorang dewasa [23].

Menurut Bar-On kecerdasan emosi-sosial terdiri daripada kemampuan, kemahiran dan fasilitator emosi dan sosial. Semua elemen ini saling berkaitan dan bekerjasama. Mereka memainkan peranan penting dalam seberapa berkesan kita memahami diri kita sendiri dan orang lain, seberapa mudah kita mengekspresikan diri kita, tetapi juga bagaimana kita menangani tuntutan harian [33].

\section{Kajian Lepas}

Dalam kajian literatur, terdapat banyak bukti yang menunjukkan bahawa keberkesana kepemimpinan berkorelasi secara signifikan dengan kecerdasan emosi $[1,2,3,4,7,8,11]$.

Berdasarkan kajian dalam jangka masa tiga dekad, Klemp (2005) mencatat beberapa aspek utama kecerdasan emosi yang sangat berkaitan dengan keberkesanan kepemimpinan [34]. Dia menekankan bahawa bukan sahaja pemimpin yang berkesan menyedari kesannya terhadap orang lain, tetapi mereka menggunakan kesan ini untuk keuntungan mereka. Pemimpin yang paling berkesan, lanjutnya, membuat keputusan yang sukar sambil menunjukkan empati secara berturut-turut semasa prosesnya. Klemp, lebih jauh, menyatakan bahawa pemimpin yang paling berkesan, yang menunjukkan tahap kecerdasan emosi yang tinggi, bersemangat dengan apa yang mereka lakukan, adalah komunikator yang sangat baik, dan mahir menyeimbangkan perasaan dan logik ketika membuat keputusan [34].

Kecerdasan emosi juga disebut-sebut mempunyai kepentingan relatif dalam prestasi kerja bawahan pemimpin yang berkesan. Dalam pemeriksaan mereka terhadap syarikat yang mempunyai keuntungan yang tinggi, Di Fabio \& Saklofske (2018) menunjukkan bahawa rakan sebaya dan / atau penyelia dengan kecerdasan emosi yang tinggi mendapat kenaikan gaji yang lebih tinggi dan memgang jawatan yang lebih tinggi daripada rakan sejawatnya di dalam syarikat tersebut [2].

Kim (2018) berpendapat bahawa pemimpin dengan tahap kecerdasan emosi yang tinggi sangat diperlukan untuk mencapai kejayaan dalam mana-mana organisasi formal [4]. Pemimpin yang berkesan mesti berempati dengan pekerja, memahami perasaan mereka di persekitaran kerja, membantu setiap kali ada masalah, dapat mengawal emosi mereka sendiri, dan memahami norma sosio-politik yang berfungsi dalam organisasi. Selanjutnya, pemimpin yang berkesan mempengaruhi tahap prestasi sesebuah organisasi dengan mewujudkan persekitaran kerja tertentu (menggunakan dimensi kecerdasan emosi dan sosial) yang paling sesuai untuk jenis profesion tertentu.

Begitu juga, Prezerakos (2018) melakukan kajian eksplorasi mengenai hubungan antara ukuran kemampuan kecerdasan emosi, keperibadian, kecerdasan kognitif, dan keberkesanan kepemimpinan di kalangan jururawat di hospital yang terpilih. Keberkesanan kepemimpinan dinilai menggunakan penilaian prestasi, yang melibatkan setiap peringkat bawahan pemimpin dan penilaian pengurus langsung [11]. Mengesahkan penemuan Rathore \& Pandey (2018), Prezerakos (2018) menunjukkan bahawa kecerdasan emosi yang lebih tinggi dikaitkan dengan keberkesanan kepemimpinan yang lebih tinggi. Sejauh ini, sangat jelas bahawa kecerdasan emosi dan keberkesanan kepemimpinan 
adalah dua faktor yang berkaitan secara signifikan yang mesti bekerja secara rapat untuk mendapatkan hasil organisasi yang terbaik [7].

Walaupun kecerdasan emosi merupakan perkara yang perlu diberikan perhatian di era globalisasi ini, namun kajian untuk melihat keperluannya masih kurang dijalankan di Malaysia. Justeru itu, kajian ini dijalankan bagi megenalpasti hubungan antara kecerdasan emosi dan keberkesanan kepimpinan dalam kalangan jurulatih di pusat latihan XYZ.

\section{Metodologi Kajian}

Reka bentuk kajian adalah berdasarkan kepada persoalan dan objektif kajian. Ia dapat memberikan garis panduan kepada pengkaji dalam pemilihan jenis data dan sumber kajian yang akan digunakan. Secara amnya, reka bentuk kajian akan dapat memberikan jawapan kepada soalan-soalan seperti apakah teknik yang akan digunakan dalam pengumpulan data dan apakah jenis persampelan kajian [35].

Dalam kajian ini, set lengkap borang soal selidik yang berjumlah 74 telah diedarkan kepada peserta yang telah menyertai Program Transformasi (Team Building) anjuran pusat latihan XYZ pada 20 Oktober 2018 sehingga 22 Oktober 2018. Soal selidik kajian ini mengandungi 30 soalan yang dibahagikan kepada tiga bahagian yang utama iaitu bahagian A: maklumat diri responden; bahagian B: kecerdasan emosi; dan bahagian C: keberkesanan kepimpinan.

Kajian rintis merupakan kajian awal yang dijalankan untuk mengukur tahap kefahaman dan kesesuaian soalan soal selidik sebelum soal selidik tersebut digunakan untuk tujuan pengumpulan data. Dalam kajian ini, nilai Alpha Cronbach yang di catatkan secara keseluruhan adalah 0.766 , ini bererti instrumen kajian ini mempunyai kebolehpercayaan yang tinggi untuk mengumpulkan maklumat dengan tepat.

Data yang diperolehi dianalisis dengan menggunakan kaedah analisis diskriptif yang menerangkan taburan kekerapan, peratusan, dan min skor bagi menjawab objektif satu dan dua. Manakala untuk menjawab objektif dua ujian pekali kolerasi Pearson digunakan untuk menentukan hubungan antara pembolehubah bersandar dan pembolehubah bebas.

\section{Dapatan dan Perbincangan}

Berdasarkan hasil soaljawab soalan soal selidik yang telah dijalankan kepada resonden, pecahan bagi demografi responden telah dijelaskan di dalam jadual 1 di bawah.

Jadual 1 - Demografi responden

\begin{tabular}{|c|c|c|}
\hline Kategori & Kekerapan & Peratusan (\%) \\
\hline \multicolumn{3}{|l|}{ Jantina } \\
\hline Lelaki & 33 & 36.5 \\
\hline Perempuan & 41 & 65.0 \\
\hline \multicolumn{3}{|l|}{ Tidak menjawab } \\
\hline \multicolumn{3}{|l|}{ Keturunan } \\
\hline Melayu & 39 & 57.1 \\
\hline Cina & 9 & 7.9 \\
\hline India & 15 & 17.4 \\
\hline Bumiputera Sabah & 6 & 7.9 \\
\hline Bumiputera Sarawak & 3 & 1.5 \\
\hline Tidak menjawab & 2 & 3.1 \\
\hline \multicolumn{3}{|l|}{ Umur } \\
\hline 19-23 tahun & 30 & 47.6 \\
\hline 24-28 tahun & 27 & 26.9 \\
\hline 29-33 tahun & 6 & 9.5 \\
\hline 34 tahun dan ke atas & 11 & 15.8 \\
\hline Tidak menjawab & - & \\
\hline \multicolumn{3}{|l|}{ Tahap Pendidikan } \\
\hline UPSR / SRP/PMR & 2 & 3.1 \\
\hline SPM / SPMV & 36 & 57.1 \\
\hline STPM / diploma & 14 & 11 \\
\hline Sijil Kemahiran & 15 & 23.8 \\
\hline Ijazah Sarjana & 4 & 6.3 \\
\hline \multicolumn{3}{|l|}{ Status } \\
\hline Bujang & 46 & 68.2 \\
\hline
\end{tabular}




\begin{tabular}{lll} 
Berkahwin & 24 & 22.2 \\
Duda/janda & 4 & 9.5 \\
\hline
\end{tabular}

Jadual diatas menunjukkan profile responden kajian seramai 74 orang yang terdiri daripada Jurulatih di Pusat Latihan XYZ. Berdasarkan dapatan, 65 peratus jurlatih yang memberi maklumbalas soal selidik ini adalah perempuan yang majoritinya berbangsa Melayu. Manakala umur jurulatih adalah 47.6 peratus diantara 19 hingga 23 tahun dan hanya 15.8 peratus berada di peringkat umur 34 tahun keatas. Separuh daripada responden kajian mempunyai kelayakan akademik diperingkat SPM diikuti dengan 23.8 peratus yang memiliki Sijil Kemahiran.

Jadual 2 - Tahap kecerdasan emosi

\begin{tabular}{lll}
\hline & Tahap & Kekerapan /Peratusan \\
\hline $\mathbf{1 . 0 0}-\mathbf{2 . 3 3}$ & Rendah & $25(33.7 \% \%)$ \\
\hline $\mathbf{2 . 3 4}-\mathbf{3 . 6 7}$ & Sederhana & $35(47.2 \%)$ \\
\hline $\mathbf{3 . 6 8}-\mathbf{5 . 0 0}$ & Tinggi & $14(18.9 \%)$ \\
\hline
\end{tabular}

Berdasarkan kepada jadual diatas, dapatan menunjukkan tahap kecerdasan emosi adalah sederhana dengan catatan sebanyak 47.2 peratus. Manakala seramai 25 responden menyatakan kecerdasan emosi dalam kalangan jurulatih di tahap rendah. Hanya 18.9 peratus memberi maklumbalas bahawa kecerdasan emosi di tahap tinggi. Ini dapat diperjelaskan dengan memaparkan tiga min terendah bagi item pengukuran kecerdasan emosi iaitu menegur kesalahan dengan berhikmat mencatatkan nilai min 2.16, dapat mengawal emosi ketika marah (2.28) dan membuat keputusan dan tindakan dengan emosi (2.64).

Jadual 3 - Tahap keberkesanan kepimpinan

\begin{tabular}{lll}
\hline & Tahap & Kekerapan /Peratusan \\
\hline $\mathbf{1 . 0 0}-\mathbf{2 . 3 3}$ & Rendah & $5(6.7 \%)$ \\
\hline $\mathbf{2 . 3 4}-\mathbf{3 . 6 7}$ & Sederhana & $36(48.6 \%)$ \\
\hline $\mathbf{3 . 6 8}-\mathbf{5 . 0 0}$ & Tinggi & $33(44.5 \%)$ \\
\hline
\end{tabular}

Merujuk kepada jadual 3 tahap keberkesanan kepimpinan diatas, 48.6 peratus menyatakan tahap kepimpinan sederhana manakala, 44.5 peratus yang mewakili 33 responden, memberi maklumbalas bahawa keberkesanan kepimpinan jurulatih adalah di tahap tinggi. Hanya 6.7 peratus mencatatkan tahap kepimpinan yang rendah. Ini dapat dijelaskan dengan tiga nilai bacaan min yang tinggi bagi item soalan, menitik beratkan aspek displin (4.07) diikuti dengan item menekankan kualiti kerja (3.74) dan arahan yang jelas (3.58)

Jadual 4 - Hubungan antara hubungan diantara kecerdasan emosi dan keberkesanan kepimpinan

\begin{tabular}{|c|c|c|c|c|}
\hline & & & Kecerdasan emosi & Keberkesanan kepimpinan \\
\hline \multirow[t]{8}{*}{ Pearson } & \multirow[t]{4}{*}{ Kecerdasan emosi } & Korelasi & 1.000 & $0.828^{* *}$ \\
\hline & & Koefiesen & & \\
\hline & & Sig (2-tailed) & & 0.000 \\
\hline & & $\mathrm{N}$ & 74 & \\
\hline & \multirow[t]{4}{*}{ Keberkesanan kepimpinan } & Korelasi & $0.828 * *$ & 1.000 \\
\hline & & Koefiesen & & \\
\hline & & Sig (2-tailed) & 0.000 & \\
\hline & & $\mathrm{N}$ & & 74 \\
\hline
\end{tabular}

** korelasi adalah signifikan pada aras 0.01

Jadual di atas menunjukkan analisis hubungan antara kecerdasan emosi dengan keberkesanan kepimpinan. Berdasarkan analisis yang dijalankan dapatan memaparkan terdapat hubungan signifikan yang positif diantara kecerdasan emosi dengan kebekesanan kepimpinan. Ini bermaksa semakin baik kecerdasan emosi, maka semakin baik tahap keberkesanan kepimpinan seseorang. Hasil analisis korelasi mencatatkan nilai 0.828 iaitu berada pada tahap korelasi yang tinggi dengan aras signifikan 0.01. Ini menunjukkan terdapat hubungan yang signifikan positif diantara kecerdasaran emosi dengan keberkesanan kepimpinan. 


\section{Cadangan dan Kesimpulan}

Kajian ini dijalankan bagi mejelaskan hubungan antara kecerdasan emosi dan keberkesanan kepimpinan dalam kalangan jurlatih di pusat latihan XYZ. Oleh itu, kajian ini mencadangkan supaya sebuah kajian pada masa akan datang dijalankan supaya melibatkan populasi jurulatih daripada latihan yang berbeza dengan membuat perbandingan. Pengkaji juga menggalakkan penggunaan kaedah campuran yang mana melibatkan kualitatif dan kuantitatif bagi mendapatakan maklumat dan penjelasan lanjut. Model kecerdasan emosi yang digunakan dalam kajian ini ialah model oleh Daniel Goleman (2000). Kajian pada masa akan datang boleh dikembangkan dengan mengggunakan model yang berbeza bagi menguji tahap kecerdasan emosi.

Hasil dapatan untuk objektif pertama kajian menunjukkan tahap kecerdasan emosi adalah sederhana dengan catatan sebanyak 47.2 peratus. Begitu juga dengan objektif kedua di mana tahap keberkesanan kepimpinan jurualtih berada di tahap sederhana. Manakala objektif ketiga pula, Berdasarkan analisis yang dijalankan dapatan memaparkan terdapat hubungan signifikan yang positif diantara kecerdasan emosi dengan kebekesanan kepimpinan. ini bermaksa semakin baik kecerdasan emosi, maka semakin baik tahap keberkesanan kepimpinan seseorang. Hasil analisis korelasi mencatatkan nilai 0.828 iaitu berada pada tahap korelasi yang tinggi dengan aras signifikan 0.01. ini menunjukkan terdapat hubungan yang signifikan positif diantara kecerdasaran emosi dengan keberkesanan kepimpinan.

Hasil dapatan kajian ini adalah selari dengan kajian yang telah dijalankan oleh Baesu (2019) yang menyatakan bahawa kecerdasan emosi pemimpin dapat membantu meningkatkan produktiviti pekerja [3]. Menurut Edelman \& van Knippenberg (2018), kecerdasan emosi dikaitkan dengan keberkesanan kepimpinan [1]. Jurulatih yang mempunyai kecerdasan emosi akan turut mahir dalam mengenal pasti, menafsirkan, dan bertindak balas terhadap emosi: oleh itu adalah wajar untuk mengharapkan bahawa mereka akan mempunyai kecenderungan yang lebih besar untuk menguruskan pelatihnya dengan berkesan. Begitu juga, jurulatih yang mempunyai kecerdasan emosi yang tinggi dapat melihat dan menafsirkan rangsangan organisasi secara berbeza, dan melakukan corak tingkah laku yang berbeza daripada mereka yang mempunyai kecerdasan emosi yang lebih rendah.

\section{Penghargaan}

Penulis ingin mengucapkan terima kasih kepada Fakulti Teknologi dan Perniagaan, Universiti Tun Hussein Onn Malaysia atas bantuan dan maklumat yang diberikan untuk memastikan kejayaan kajian ini.

\section{Rujukan}

[1] Edelman P, \& van Knippenberg D 2018 Emotional intelligence, management of subordinate's emotions, and leadership effectiveness Leadership \& Org. Dev. J

[2] Di Fabio A, \& Saklofske D H 2018 The contributions of personality and emotional intelligence to resiliency Personality and Individual Differences vol 123 p 140-144

[3] Baesu C 2019 Leadership based on emotional intelligence in modern organizations The USV Annals of Economics and Public Administration Vol 18 p 73-78

[4] Kim J I 2018 The Effects of Emotional Intelligence, Self-Leadership, Psychological Well-being to Academic Achievement of Nursing College Student J. of the Korea Academia-Industrial cooperation Society Vol 19(12) p $574-583$

[5] Siegler R 1992 The other Alfred Binet Developmental Psychology Vol 28(2) p 178-190

[6] Wills A 2018 Emotional and spiritual intelligence in the workplace in relation to organizational citizenship behavior (Doctoral dissertation, Kaplan University)

[7] Rathore S, \& Pandey R 2018 Reviewing emotional intelligence with leadership theory: a study of the role of emotional intelligence on transformational leadership In Management Strategies and Technology Fluidity in the Asian Business Sector p 1-13 IGI Global

[8] Wang L, Tao H, Bowers B J, Brown R, \& Zhang Y 2018 When nurse emotional intelligence matters: How transformational leadership influences intent to stay J. of nursing management, Vol 26(4) p 358-365

[9] Makkar S, \& Basu S 2019 The impact of emotional intelligence on workplace behaviour: A study of bank employees Global Business Review Vol 20(2) p 458-478

[10] Pool L D, \& Qualter P 2018 An introduction to emotional intelligence John Wiley \& Sons

[11] Prezerakos P E 2018 Nurse managers' emotional intelligence and effective leadership: A review of the current evidence The open nursing journal Vol 12 p 86

[12] Suwandana I G M 2019 Role of transformational leadership mediation: effect of emotional and communication intelligence towards teamwork effectiveness Int. research j.l of management, IT and social sciences Vol 6(2) p $52-62$

[13] Lussier R 2012 Human relations in organizations: Applications and skill building McGraw-Hill Higher Education

[14] Caldwell C 2012 Moral Leadership: A Transformative Model for Tomorrow's Leaders Business Expert Press

[15] Kouzes J M, \& Posner B Z 2012 The Leadership Challenge: How to Make Extraordinary Things Happen in Organizations Jossey-Bass 
[16] DePree M 2011 Leadership is an art Crown Business

[17] Paine L 2002 Value shift: Why companies must merge social and financial imperatives to achieve superior performance McGraw Hill Professional

[18] Hernandez M 2012 Toward an understanding of the psychology of stewardship. Academy of Management Review vol 37(2) p172-193

[19] Treviño L K, Hartman L P, \& Brown M 2000 Moral person and moral manager: How executives develop a reputation for ethical leadership California management review vol 42(4) p 128-142

[20] Cameron K 2011 Responsible leadership as virtuous leadership Journal of Business Ethics Vol 98(1) p25-35

[21] Shao R, Aquino K, \& Freeman D 2008 Beyond moral reasoning: A review of moral identity research and its implications for business ethics Business Ethics Quarterly vol 18(04) p 513-540

[22] Hosmer L T, \& Hosmer L R T 2010 The ethics of management (p. 169) Homewood IL Irwin.

[23] Lennick D, \& Kiel F 2008 Moral Intelligence: Enhancing Business Performance \& Leadership Success (Wharton Business School Publishing, Upper Saddle River, NJ)

[24] Covey S R 2013 The 8th habit: From effectiveness to greatness Simon and Schuster

[28] Kunnanatt J T 2004 Emotional intelligence: The new science of interpersonal effectiveness. Hum. Resour. Dev. Q. p 489-495. doi: 10.1002/hrdq.1117

[29] Goleman D 2001 Emotional intelligence: Issues in paradigm building In The Emotionally Intelligent Workplace: How to Select for, Measure, and Improve Emotional Intelligence in Individuals, Groups, and Organizations Vol 13 Jossey-Bass San Francisco CA, USA p. 26

[30] Goleman D P 1995 Emotional Intelligence: Why it Can Matter More than IQ for Character, Health and Lifelong Achievement Bantam Books New York USA

[25] Mayer J D, Roberts R D, Barsade S G 2008 Human abilities: Emotional intelligence. Annu. Rev. Psychol. Vol 59 p 507-536. doi: 10.1146/annurev.psych.59.103006.093646

[26] Gutiérrez-Cobo M J, Cabello R, Fernández-Berrocal P 2016 The relationship between emotional intelligence and cool and hot cognitive processes: A systematic review Front. Behav. Neurosci. Vol 10 p 101

[27] Salovey P, Mayer J D 1990 Emotional intelligence Imagin. Cogn. Personal vol 9 p 185-211. Doi: 10.2190/DUGG-P24E-52WK-6CDG

[31] Mayer J D, Salovey P, Caruso D R, Sitarenios G 2003 Measuring emotional intelligence with the MSCEIT V2. 0. Emotion. Vol 3 p $97-105$

[32] Mayer J D 2000 Emotion, intelligence, and emotional intelligence In: Forgas JP editor Handbook of Affect and Social Cognition. Erlbaum; Mahwah, NJ, USA p 410-431.

[33] Bar-On R 2006 The Bar-On model of emotional-social intelligence (ESI) Psicothema vol 18 p 1- 28

[34] Klemp G 2005 Emotional intelligence and leadership: What really matters Boston, MA: Cambria Consulting, Inc.

[35] McKenney S E, \& Reeves T C 2012 Conducting educational research design: What, why and how Taylor \& Francis 